\title{
小学校教室における昼光利用の実態と促進に関する研究 A STUDY ON THE ACTUAL STATUS AND PROMOTION OF DAYLIGHT USE IN ELEMENTARY SCHOOL CLASSROOM
}

\author{
芹 澤彰典 ${ }^{* 1}$, 上野 佳奈子*2, 橋 本 都子*3 \\ Akinori SERIZAWA, Kanako UENO and Kuniko HASHIMOTO
}

\begin{abstract}
In recent years, in the design of school facilities aimed at saving energy, window design is contrived to realize daylight use. This study aims to reveal the light environment of classrooms with contrived windows, the use of artificial lighting and light shielding devices, and the problems and possibilities of daylight use in school buildings. In two elementary schools, we conducted the measurement and a survey. Additionally, we performed a trial to reduce the amount of artificial lighting with the cooperation of teachers and children. From the results, the design and operation methods required to promote daylight use were summarized.
\end{abstract}

Keywords : Elementary School, Daylight Utilization, Actual Use, Energy Saving, Case Study 小学校, 昼光利用, 使い方, 省エネルギー, 事例研究

\section{1. はじめに}

小学校の教室では、建築基準法により開口率を $1 / 5$ 以上とするこ とが定められており、大きな空開口が設けられる。学校教室の大き さは、一般に 4 間 $\times 5$ 間 $(7.2 \mathrm{~m} \times 9.0 \mathrm{~m})$ が原型となっている ${ }^{1), ~}$ 注 1)。そのため、この床面積で考えると、南面片側採光が一般的な従 来の標準設計型校舎の教室では、黒板左手の側壁の $1 / 2$ 程度が空と なっている場合が多い。しかし、これは空際と室奥との照度差・輝 度差が大きくなり、直射日光のまぶしさも生じるという点で、視環 境的には改善の余地がある。

一方、近年では省エネルギーを目指した設計において、採光に工 夫がなされる事例が増えてきている。学校施設においては、消費エ ネルギーに占める照明エネルギーの割合が $45 \%$ 程度と高いことか ら ${ }^{2)}$ 、昼光により教室の明るさを確保することで大きなエネルギー 削減効果が期待できる。しかしながら、空面積を大きくとり、より 多くの昼光を取り入れることが照明エネルギー削減に直結するわけ ではない。昼光の導入量が大きいと空間の明るさ感を低下させると の指摘もあり ${ }^{3 ）}{ }^{4)}$ 、単に昼光を取り入れるのではなく、まずは採光 方式や遮光装置の工夫などの建築的手法によって均斉度の向上やま ぶしさの排除がなされる必要がある。さらには、昼光による明るさ に応じた人工照明の点滅という使用者側の調整行動が伴って、初め て照明エネルギー削減が実現する。近年では、学校施設を利用し、 住環境プログラムの作成と実施を行うことで、環境に配慮した住ま い方の意義の習得を目指した研究報告もある ${ }^{5 ｝ \text { ～7）が、普及には至 }$ っていない。そのため、季節や方位によって変わる太陽からの直射 日光に応じて、適切な遮光や人工照明の調節を行うことは、学校の
使用者である教員・児童にとって容易なことではなく、使用者の環 境調整行動も含めて学校の採光・照明計画の課題を整理することが 必要と考えられる。

本研究では、積極的な昼光利用を目指して設計がなされた小学校 2 校を対象にし、対象校 2 校における昼光利用の実態と課題、昼光 利用における課題の改善の可能性を示すことを目的とし、光環境の 測定と、遮光装置及び人工照明の使用状況の調查を行った。さらに、 教員・児童の協力を得て、人工照明の使用削減に向けた取組みを行 い、照明によるエネルギー使用量削減の可能性について考察した。

\section{2. 研究協力校の概要}

研究協力校は、千葉県千葉市立美浜打瀬小学校（以下 $\mathrm{M}$ 小）及び 東京都立川市立第一小学校（以下 $\mathrm{T}$ 小）であり、学校建築作品で優 れた実績をもつ同一のアトリエ系設計事務所が設計を手掛けている。 $\mathrm{M}$ 小は建築学会作品選奨他、 $\mathrm{T}$ 小は BCS 賞を受賞しており、とも に高い評価を受けた学校建築で先進的な事例と位置付けられる。各 校の光環境の測定対象教室の平面図を Fig.1 に示す。なお、Fig.1 の教室名は、学校をアルファベット、学年クラスを数字として示し ている（M1-3 であれば、 $\mathrm{M}$ 小の 1 年 3 組教室)。

M小は 2006 年に竣工し、並列と対向に配置されたオープンプラ ン教室をオープンスペース (OS) がつなぐ構成となっており、音・ 温熱・光環境を含めた学習環境づくりを重要なテーマの一つとして 設計されている ${ }^{8)}$ 。特に光環境の面では、各教室に黒板の両サイド に L 字型の側空と教室後部にハイサイド空を設けている。さらに、 教室の後方にあるオープンスペースには一定間隔ごとに天空が設け
*1 明治大学大学院理工学研究科建築学専攻 博士前期課程

*2 明治大学理工学部建築学科 教授・博士 (工学)

*3 千葉工業大学創造工学部デザイン科学科 教授・博士(学術)
Graduate School of Science and Technology, Meiji University

Prof., Dept. of Arch., School of Science and Technology, Meiji Univ., Dr.Eng.

Prof., Dept. of Design, Faculty of Creative Eng., Chiba Institute of Technology, Ph.D. 


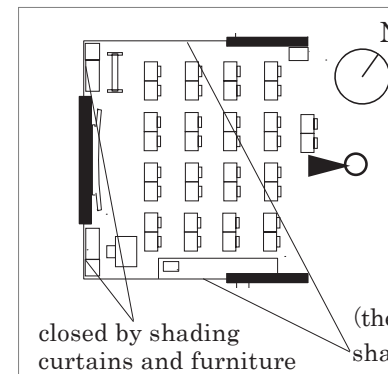

$\mathrm{N}$ high-side window southeast $;$ northwest)

curtains and furnit

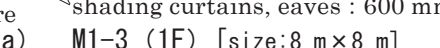
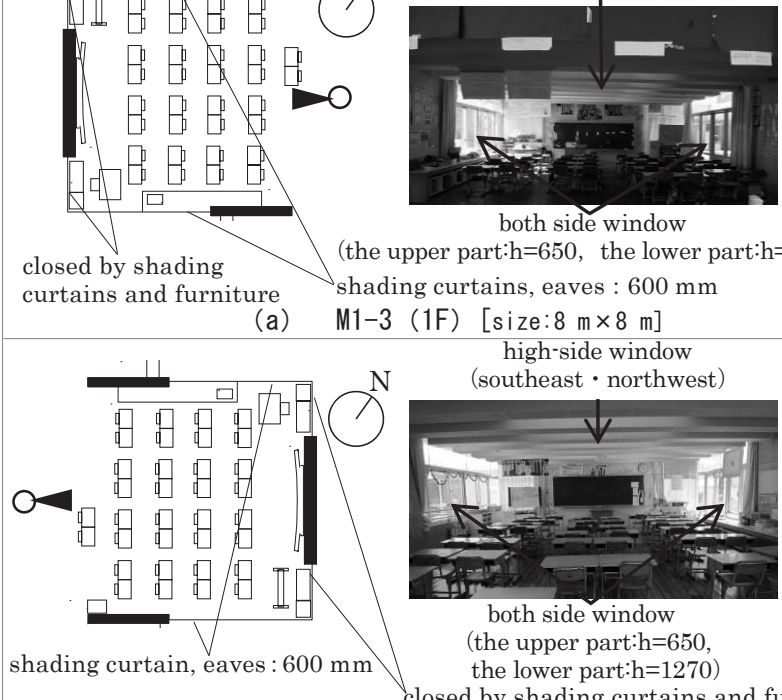

both side window he upper part: $\mathrm{h}=650$, the lower part: $\mathrm{h}=1420$ )

high-side win (southeast $\cdot$ northwest)

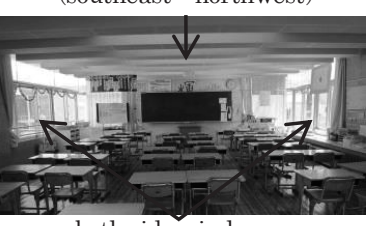

both side window

(the upper part: $\mathrm{h}=650$,

the lower part: $\mathrm{h}=1270$ )

closed by shading curtains and furniture

(b) M6-2 (2F) [size:8 m $\times 8 \mathrm{~m}]$
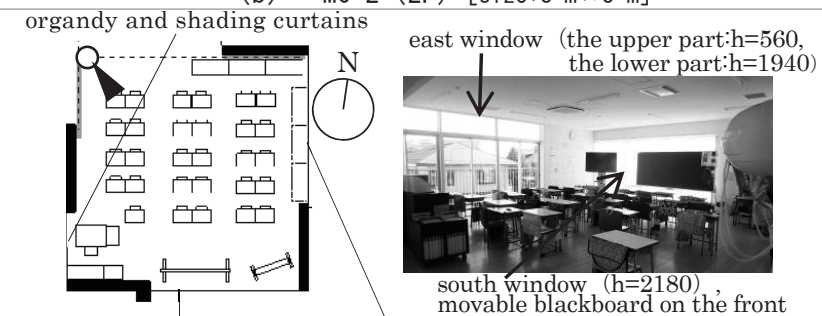

organdy and shading curtain eaves : $1200 \mathrm{~mm}$

movable blackboard on the front

organdy and shading curtain, eaves : $1300 \mathrm{~mm}$ closed by furniture in winter

(c) T2-3 (2F) [size:8.1 m×8.1 m]

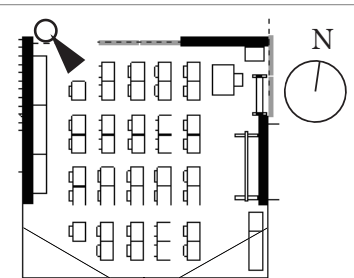

organdy and shading curtains, eaves : $350 \mathrm{~mm}$

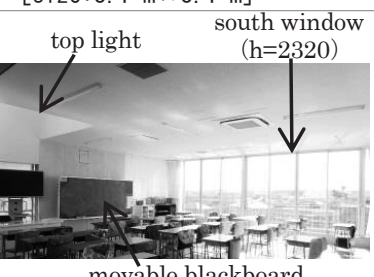

movable blackboard

(d) T6-2 (3F) $[$ size:8.1 m $\times 8.1 \mathrm{~m}]$

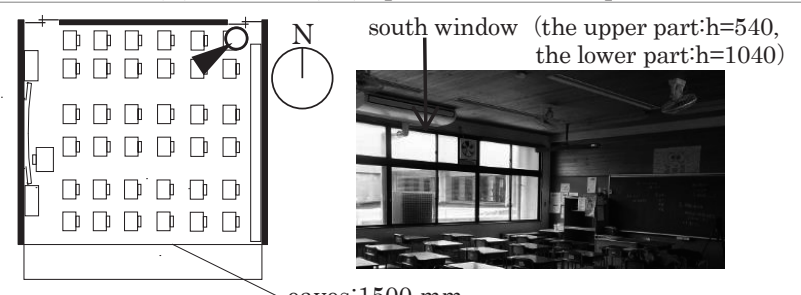

eaves:1500 mm

(e) School S (2F) [size:7.6 m×8.2 m]

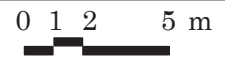

viewpoint of photo

$\mathrm{h}$ : height of windowpane $(\mathrm{mm})$

Fig. 1 Plan and photo view of measurement classrooms of I ight environment

Table 1 Measurement condition

\begin{tabular}{|c|c|c|c|}
\hline classroom & direction of window & $\begin{array}{c}\text { window of } \\
\text { curtain condition* }\end{array}$ & measurement day and time \\
\hline M1-3 & southeast $\cdot$ northwest & southeast & August 7, 2017 (sunny) ,10:00 11:00 \\
\hline M6-2 & southeast $\cdot$ northwest & southeast & December 26, 2017 (sunny) , 10:20 11:20 \\
\hline $\mathrm{T} 2-3$ & south $\cdot$ east $\cdot$ west & east $\cdot$ west & August 23, 2017 (cloudy) 11:00 12:00 \\
\hline $\mathrm{T} 6-2$ & south & south & January 14, 2018 (sunny) 10:00 11:30 \\
\hline school S & south & south & $\begin{array}{|lll|}\text { August 17, } 2017 \text { (sunny) } & 12: 10 ~ 12: 30 \\
\text { January 4, } 2018 \text { (sunny) } & 11: 40 \sim 12: 00 \\
\end{array}$ \\
\hline
\end{tabular}

$※$ direction of window of which the curtain condition was changed in winter measurement
られ、昼光を積極的に取り入れている。なお、側空は学校内部に開 いており、空外には隣接する教室が見えるものが多い。また、M小 には、児童数の増加に伴い、仮設校舎が増設されており、こちらは 通常の片側採光になっている。

T小は、2014 年に建替えにより新築され、小学校・市立図書館・ 学童保育が複合したオープンプラン型の小学校である ${ }^{9)}$ 。学級教室 は、小学校の $2 \cdot 3$ 階にあり、オープンスペースを囲むように 3 教室 を配置した学年ユニットで構成され、回遊性の高い計画となってい る。従来よりも積極的に昼光を取り入れるため、ほとんどの教室に 腰壁のない掃き出しの側空が複数面に設けられており、3 階の教室 はそれに加えて教室の一画にトップライトが設けられている。教室 に設置された黒板や家具は可動式であり、自由にレイアウトが変え られるが、黒板に補助照明はついていない。また、 $\mathrm{T}$ 小は 2 階建て の住宅が周囲に近接していることから、ガラスなどの透明な面や大 きなテラスを介すことで、外部と直結するのではなく、見え隠れし ながら街と共鳴するような状態を目指して設計されている。

\section{3. 光環境の測定 \\ 3. 1 測定方法}

特徴的な昼光の取り入れ方をしている $\mathrm{M}$ 小・T 小教室との比較を 行うために、従来の標準設計型の教室として、群馬県の公立中学校 （以下 $\mathrm{S}$ 中）の教室の測定も行った。 $\mathrm{S}$ 中は、1987 年に竣工した南 面片側採光の教室を持つ標準設計タイプの学校施設である。測定は、 各教室で夏季と冬季に行った。測定対象教室を Fig.1、測定点の一 例を Fig.2、測定条件を Table 1、各教室の空面積と開口率を Table 2 に示す。測定は、机上面照度 9 点と輝度分布 2 視点で行った注2)。 輝度分布 2 視点は、教員の立位視点 $(h=1500)$ と児童の座位視点 $(\mathrm{h}=1000)$ とした。人工照明は消灯とし、夏季ではカーテン開、冬 季ではカーテン開閉の両条件を設定した。M 小のカーテン閉の条件 は、直射日光の入射する空(南東側)のカーテンを閉めた条件とした (北西側の空のカーテンは開けている)。T 小では、オーガンジーカ

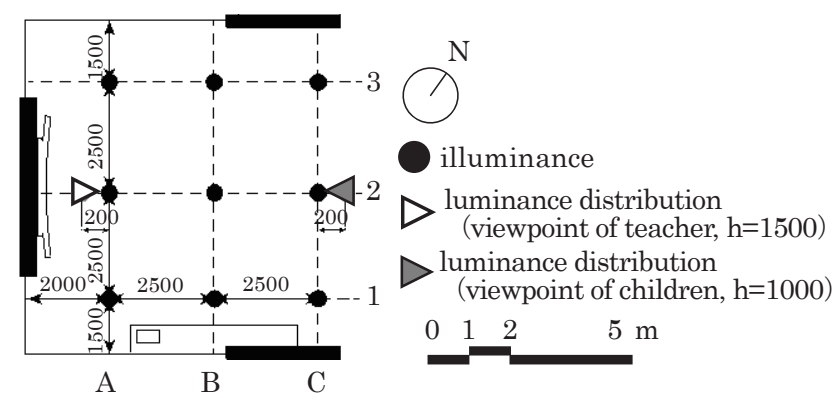

Height of desk:M1-3, T2-3;550 mm

M6-2, T6-2, school S;700 mm

Fig. 2 An example of measurement points of light environment in a classroom

Table 2 Area of windowpane and aperture ratio

\begin{tabular}{|c|c|c|c|}
\hline & $\begin{array}{c}\text { side } \\
\text { window }\left[\mathrm{m}^{2}\right]\end{array}$ & $\begin{array}{c}\text { high-side window } \\
\text { top light }\left[\mathrm{m}^{2}\right]\end{array}$ & $\begin{array}{c}\text { aperture } \\
\text { ratio[\%] }\end{array}$ \\
\hline M1-3 & 32.3 & 9.1 & 64.7 \\
\hline M6-2 & 25.0 & 9.1 & 53.3 \\
\hline T2-3 & 25.0 & & 38.1 \\
\hline T6-2 & 28.2 & 4.9 & 50.4 \\
\hline school S & 10.8 & & 17.6 \\
\cline { 1 - 3 } & & &
\end{tabular}


ーテン及び遮光カーテンの 2 種類のカーテンをそれぞれ閉めた条件 とした。また、両小学校とも黒板背面にある空は常にカーテンを閉 めて教室を使用していたことから、全ての条件で黒板背面の空はカ ーテンを閉とした。なお、直射日光のあたっていた教室内（密以外） の部分は、照度と輝度ともに測定結果から除外している注3)。

\section{2 光環境の測定結果}

\section{(1) 机上面照度}

夏季・冬季の机上面照度の実測結果から、 $\mathrm{A} \sim \mathrm{C}$ 各列 (Fig.2 参照) の平均を算出し Fig.3 に示寸。夏季の机上面照度については、 $\mathrm{M}$ 小・ $\mathrm{T}$ 小はどの教室も推奨值 ${ }^{10)}$ である $500 \mathrm{~lx}$ を満たしているが注4)、特 に三面採光の T2-3 や両側空と八イサイドライトのある M1-3・M6-2 では、標準設計型の $\mathrm{S}$ 中よりも窓際と室奥との照度差（照度バラン ス）は良い。一方で、T6-2 は室奥まで高照度となっているが、空際 の机上面照度も非常に高いことから、空際と室奥との照度差が大き い。これは、T6-2 が南側に大きな空面を持つためであり、照度バラ ンスでは課題がみられる。

また、冬季ではどの教室においても、カーテン開の条件では教室 内に直射日光が入射しており、カーテンを閉めざるをえない状沉で あり、その際照度は低下した。ただし、2 校とも空面積が大きいた め、遮光カーテンを閉めても教室内の照度は推奨值を満たしていた。

\section{(2) 輝度分布}

空間の明るさ感に関連がある輝度の測定結果として、教員視点の 室内平均輝度と天井面平均輝度を Fig. 4 ・ 5 に示す注 5)。 M 小・ T 小 は、夏季・冬季ともに $\mathrm{S}$ 中よりも平均輝度が高い。また、天井面平 均輝度は規準 ${ }^{11}$ 1) である $15 \mathrm{~cd} / \mathrm{m}^{2}$ を大きく超えており、昼光を積極 的に導入した効果であると考えられる。

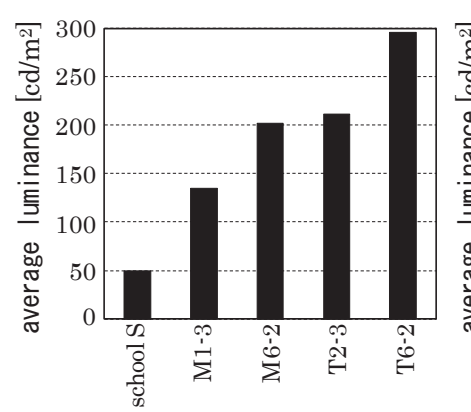

(a) Average of each classroom

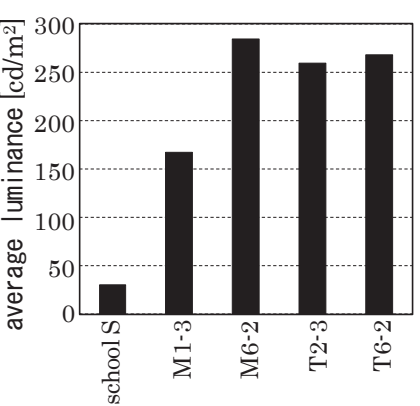

(b) Average of ceiling surface
Fig. 4 Measurement results of luminance in summer

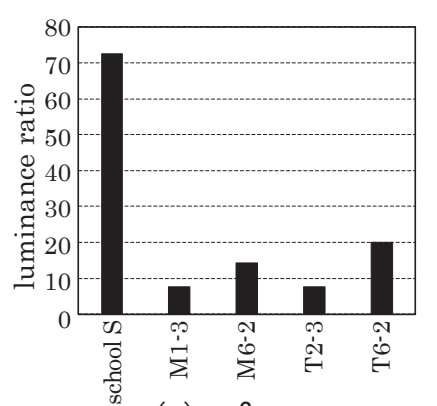

(a) Summer

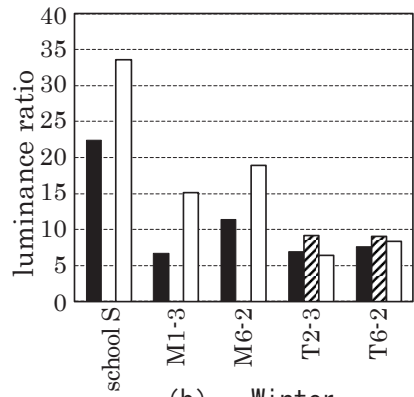

(b) Winter o curtains with organdy curtain $\square$ with shading curtain Fig. 6 Luminance ratio of window to classroom
空面と室内との輝度比（Fig.6（a））をみると、夏季では $\mathrm{S}$ 中と 比較して $\mathrm{M}$ 小・ $\mathrm{T}$ 小の教室は、輝度比は小さくなっており、明るさ 感の均一性が優れている。これは、 $\mathrm{S}$ 中よりも採光面が多いことや、 内装材が木質ではなく白色系の仕上げになっていることが影響して いると考えられる注 6)。また、直射日光を遮るためにカーテンを閉 めざるをえない冬季では、Fig.6（b）で示すとおり、特に S 中・M 小で、遮光カーテンを閉めた条件がカーテンなし条件よりも空面と の輝度比が高くなっている。直射日光を遮るためにカーテンを閉め ても、Fig.7 に示寸とおりカーテン面が発光することで高輝度面と なり、室内との輝度比が上昇したと考えられる。遮光カーテンは、

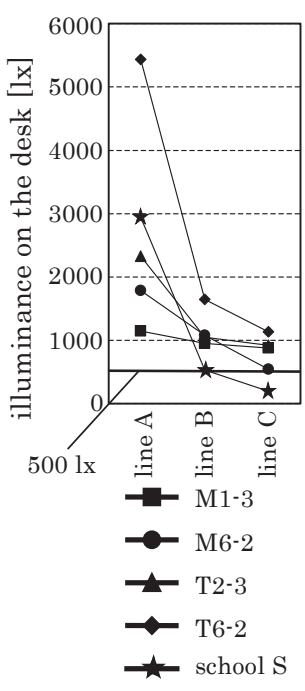

(a) three schools (summer)

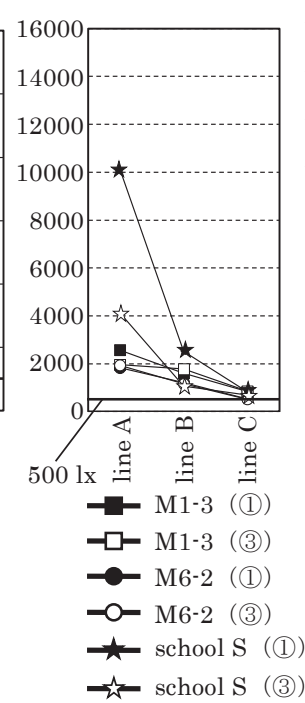

(b) school M, S (winter)

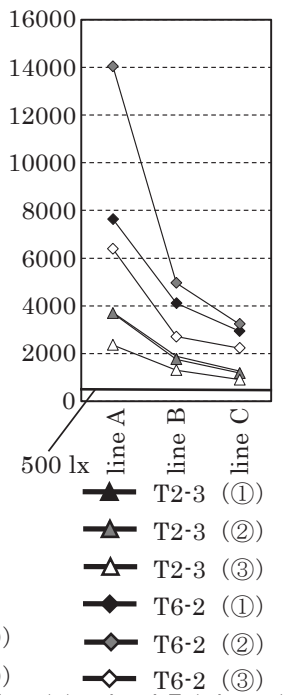

(c) school T (winter)
(1): no curtain (2): with organdy curtain (3): with shading curtain

Fig. 3 Measurement results of illuminance on the desk (summer and winter)

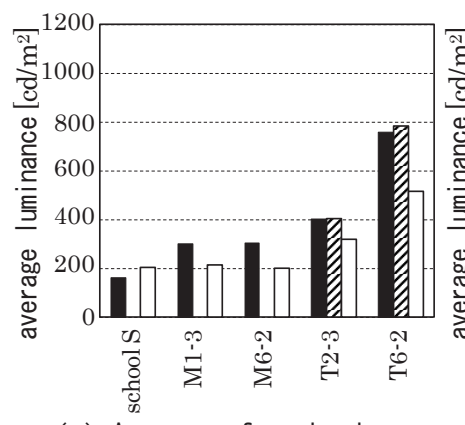

(a) Average of each classroom

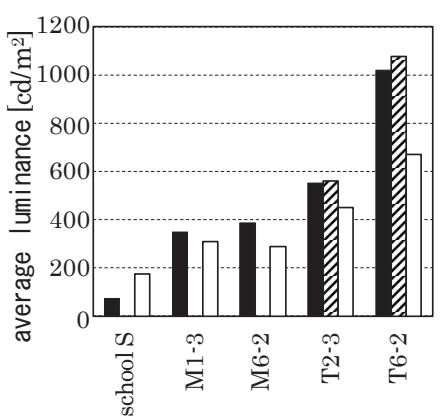

(b) Average of ceiling surface no curtains with organdy curtain with shading curtain

Fig. 5 Measurement results of Iuminance in winter

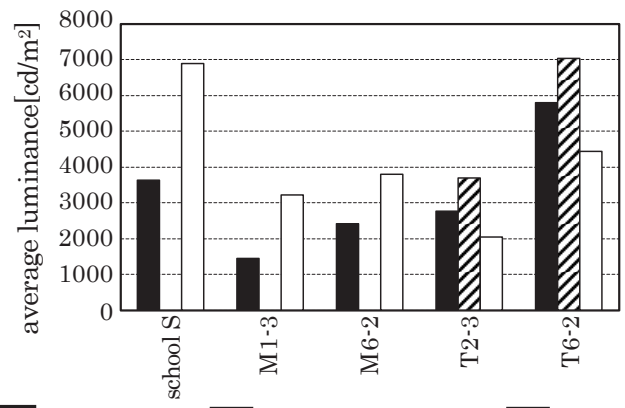

no curtains $\quad \square$ with organdy curtain $\square$ with shading curtain

Fig. 7 Luminance of window and curtain surface in winter 
一般的に学校で用いられているものであるが、室内と室外の輝度比

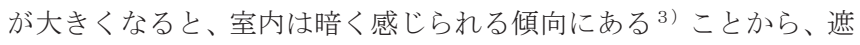
光しても空面と室内との輝度比を大きくしなしようなカーテンの素 材や別の遮光装置の検討が必要と考えられる。一方、 $\mathrm{T}$ 小では遮光 カーテン使用時に空面輝度は下がり、輝度比も T2-3 は減少、 $\mathrm{T} 6-2$ も少しの上昇しか見られなかった。空面輝度が下がった理由は、M 小や $\mathrm{S}$ 中よりもカーテンの遮光性能が高かったためと考えられる。 T2-3 で輝度比が下がった理由としては、測定視野内に入る空が東空 で、測定時間帯にはあまりカーテン面に直射日光が当たらなかった ため、カーテンが発光面にならなかったことが考えられる。T6-2 に ついては、南面に大きな空があり庇 $(350 \mathrm{~mm})$ によって直射日光 が遮蔽されていないことから、空面輝度は高いものの、室奥側にも トップライトがあることで採光が得られているため、輝度比が上が りにくかったものと考えられる。

また、オーガンジーカーテンを閉めた条件では、Fig.7 に示寸通 り T2-3・T6-2 で空面輝度の上昇がみられ、特に T6-2 では空面輝度 が教員目線で $7000 \mathrm{~cd} / \mathrm{m}^{2}$ 程度とカーテンを開けている条件よりも 高輝度になっていた。オーガンジーカーテンは、以前より T小の教 員からまぶしいとの指摘があり、輝度の測定結果においても裏づけ られた。このオーガンジーカーテンは、室内に光を取り込むことが できるが、直射日光の透過によってカーテン面全体が発光し、教員・ 児童視点でまぶしさが生じ、使用開始後に遮光カーテンが追加設置 された。直射日光の入射する空には、透過率や拡散特性に配慮して カーテンを選定する必要があるとみられる。

また、黒板が可動式である $\mathrm{T}$ 小では、 $\mathrm{T} 2-3$ において黒板を南空 面の前に配置していた。南空面の遮光には夏季にはオーガンジーカ ーテン、冬季には遮光カーテンが使用されていたが、測定日におけ る黒板とその背面の空との対比は大きく（輝度比：夏季 11.4、冬季 16.6)、黒板面が暗く感じられてしまう原因となると考えられる。

\section{4.人工照明及びカーテンの使われ方調査}

\section{1 調査概要}

人工照明及びカーテンの使用実態を明らかにすることを目的とし て、各時限に教室外部から使われ方について観察調查を行った。観 察日時を Table 3、小学校の生活時程を Table 4 に示す。また、特定 日に行った観察調查を補完する目的で、人工照明・カーテンの使用 実態や光・視環境の評価に関するアンケート調査を行った。アンケ 一ト調查の概要を Table 5 に示寸（回答の選択肢については Fig.8 -Fig.12 参照)。アンケート調査は、 $\mathrm{M}$ 小では 2017 年 8 月に、 $\mathrm{T}$ 小では 2015 年 10 月に実施し ${ }^{12)}$ 、各小学校の学級担任教員に回答 を依頼した。なお、M 小では教員に教室の光環境について説明する 機会があり、各教室中心位置の机上面照度の測定結果注7) を示した 上でアンケートを配布した（回答率：T 小 $89 \% 、 \mathrm{M}$ 小 $96 \%$ )。

\section{2 人工照明の使われ方の調査結果}

人工照明の使用状況は、 $\mathrm{T}$ 小・ $\mathrm{M}$ 小ともに「ほぼ使用する」の回 答が多かった。満足度（Fig.8）については、T 小でやや不満足側の 比率が高い傾向にある。Fig.9 に光環境の不満な点を示すが、全体 的にまぶしさや見づらさといった視環境的な課題点の回答が多い。 観察調查では、授業時はテレビを視聴するときを除き、常にすべて の人工照明を使用していた。
Table 3 Schedule of the observation survey

\begin{tabular}{|c|c|c|}
\hline & School T & School M \\
\hline 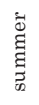 & 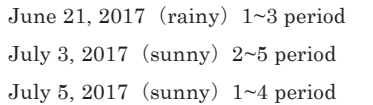 & $\begin{array}{ll}\text { July } 10,2017 \text { (sunny) } & 1 \sim 4 \text { period } \\
\text { July } 11,2017 \text { (sunny) } & 1 \sim 5 \text { period } \\
\text { July } 14,2017 \text { (sunny) } & 2 \sim 3 \text { period }\end{array}$ \\
\hline 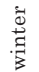 & $\begin{array}{l}\text { December 6, } 2017 \text { (sunny) 2 4 period } \\
\text { December 15, } 2017 \text { (cloudy) 2 4 period }\end{array}$ & $\begin{array}{l}\text { November 29, } 2017 \text { (sunny) 1 4 period } \\
\text { December 8, } 2017 \text { (cloudy) } 3 \sim 4 \text { period }\end{array}$ \\
\hline
\end{tabular}

Table 4 Session schedule of the elementary school

\begin{tabular}{|c|l|l|}
\hline period & \multicolumn{1}{|c|}{ school T } & \multicolumn{1}{|c|}{ school M } \\
\hline 1st & $8: 45 \sim 9: 30$ & $8: 30 \sim 9: 15$ \\
\hline 2nd & $9: 35 \sim 10: 20$ & $9: 20 \sim 10: 05$ \\
\hline 3rd & $10: 40 \sim 11: 25$ & $10: 30 \sim 11: 15$ \\
\hline 4th & $11: 30 \sim 12: 15$ & $11: 20 \sim 12: 05$ \\
\hline 5th & $13: 45 \sim 14: 30$ & $13: 30 \sim 14: 15$ \\
\hline
\end{tabular}

Table 5 Summary of the questionnaire survey

Target : School M and School T

Questions : Basic attribute, Satisfaction/dissatisfaction on the light environment in classrooms

Frequency and quantity of use of the electrical lighting, Frequency and reason of use of the curtain

Schedule :

School T ; the end of October, 2015 to mid-November

School M : from the end of August, 2017 to mid-September

Number of respondents : School T ; 18 teachers, School M ; 28 teachers

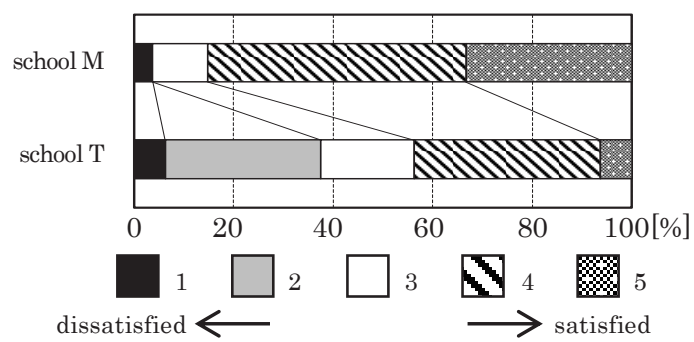

Fig. 8 Satisfaction rating of light environment in classrooms

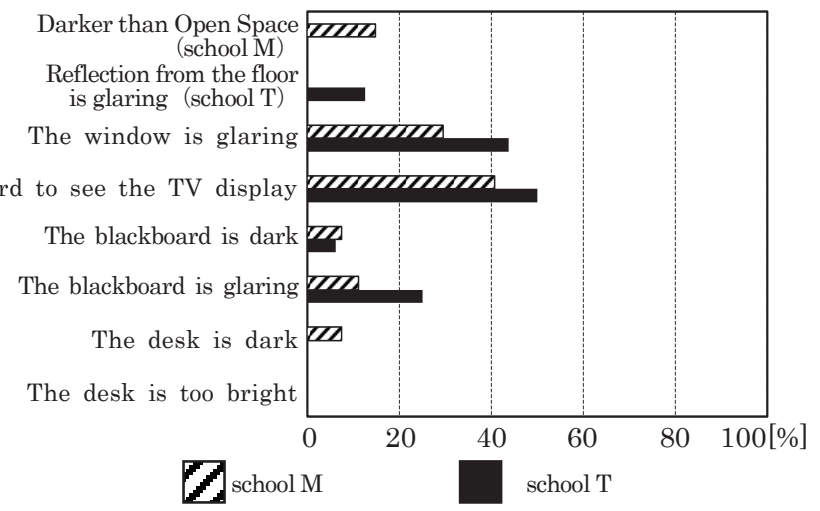

Fig. 9 Point of dissatisfaction of I ight environment in classrooms

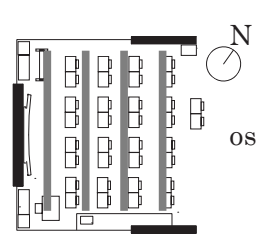

(a) School M

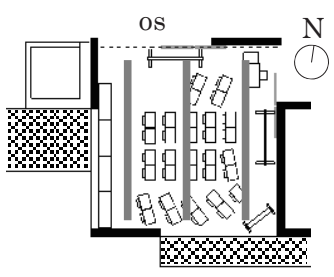

(b) School T xx deck

Fig. 10 Artificial Iighting switch pattern 


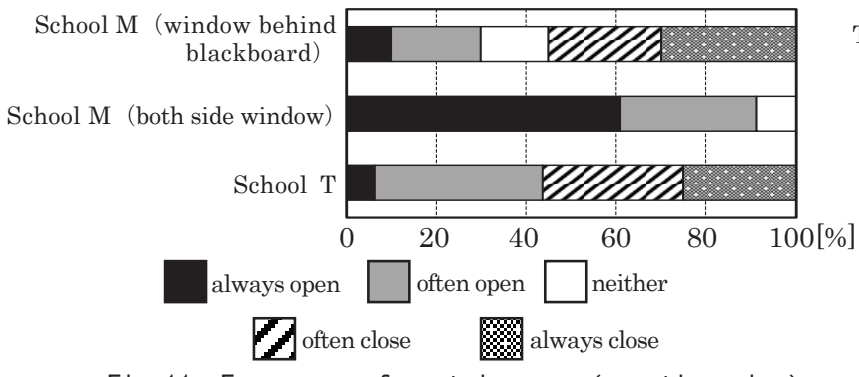

Fig. 11 Frequency of curtains use (questionnaire)

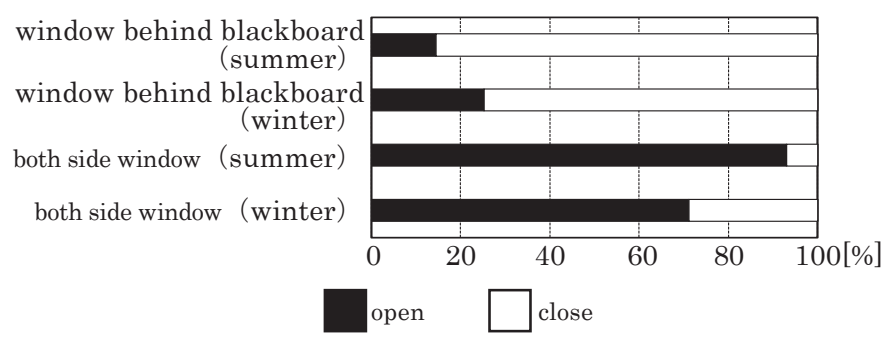

Fig. 13 Rate of curtains use at school M (observation)

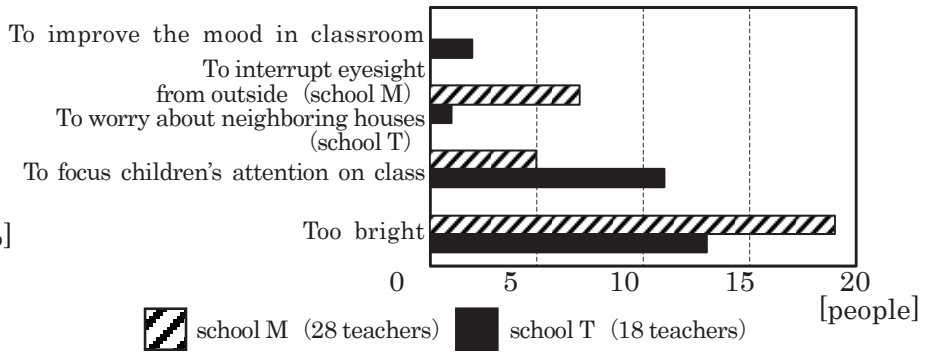

Fig. 12 Reason of using curtains (questionnaire)

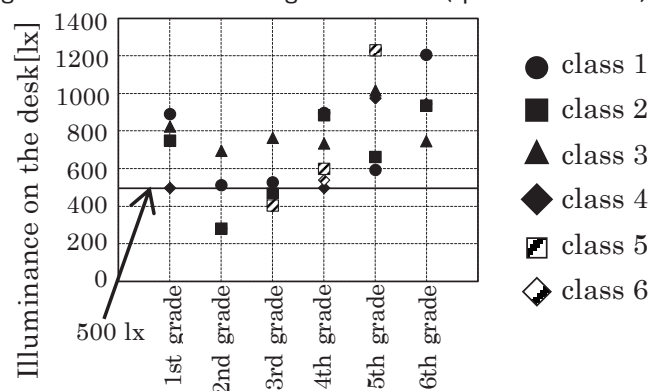

Fig. 15 Illuminance on the desk of school M (sunny)

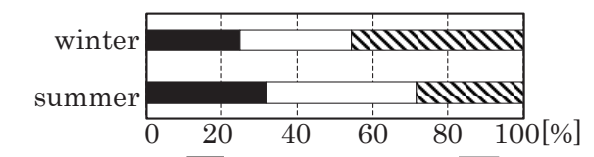

no curtains

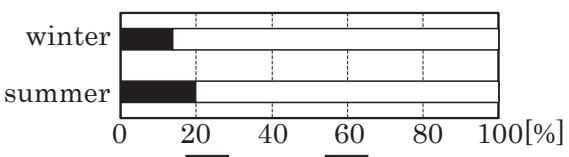

open

(b) Windows facing neighboring houses and behind blackboard

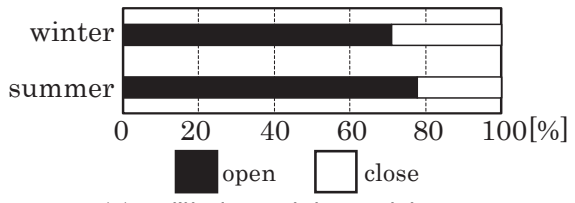

(c) Windows with no object to block visibility outside

Fig. 14 Rate of curtains use at T elementary school (observation)

Fig.10 に $\mathrm{M}$ 小・ $\mathrm{T}$ 小の人工照明の点灯パターンを示す。 $\mathrm{M}$ 小で は、全教室で人工照明の配列に対して左右対称に空が配置されてお り、昼光から得られる明るさに応じて人工照明の使用量を調整する ことができる。一方で、T小では、照明の配列と空との関係性は教 室によって異なっているが、Fig.10（b）のように 3 列で分灯して いる教室が多い注8)。そのため、十分に明るい場所があっても、そ の場所を消灯し、暗い場所を点灯するといった調節が難しい。

このことから、昼光利用により人工照明の使用量を削減するには、 空の配置に応じた人工照明の分灯方式の配慮が必要といえる。また、 使用者に対し教室に必要な明るさを示し、昼光から得られる明るさ に応じて使用量を調節するように働きかけを行っていけば、削減 できる可能性があると考えられる。

\section{3 カーテンの使われ方の調査結果}

アンケート結果では、カーテンの使用頻度（Fig.11）は T 小では 閉めている側の回答が多く、M 小では黒板背面の空は閉める側、両 サイドの窓は開ける側の回答が多かった。使用理由（Fig.12）注9) では、まぶしいためと回答する教員が両校とも半数以上いた。また、 まぶしさに次いで、外部からの視線を遮るためや児童を授業に集中 させるためとの回答が多い。 $\mathrm{M}$ 小では、自由記述においても、「外 からの刺激を防ぐために常にカーテンを閉めている」、「学校のカー テンは外からの情報を遮る役割が強いと思う」との記述もあり、直 射日光の遮蔽以外にもカーテンが使用されている実態がうかがえる。

M 小のカーテンの使用状況の観察結果を Fig.13 に示す。黒板背 面の空のカーテンは、夏季・冬季で 8 割程度閉じられていた。また、 教室の両側空のカーテンは、夏季では 9 割程度開けられているが、 冬季になるとカーテン閉の割合が上がっている。これは、冬季にな
り直射日光の入射する南東空で、直射日光を遮るために遮光カーテ ンを閉じたためである。 $\mathrm{M}$ 小の多くの教室の空は学校内部に開かれ ており、そのような空は外部からの視線等の刺激を受けることがな く、直射日光を遮る目的でカーテンが使用されていたとみられる。 ただし、来校者が使用する玄関へ行くための通路に面する校庭側の 1 教室では、時々視界の遮断にカーテンを閉じている様子が見られ た。また、増設された教室の空には道路側に開かれたものもあり、 その教室は常にカーテンを閉じていた。

T 小のカーテンの使用状況の観察結果を Fig.14 に示す。T小では、 カーテンの使用率が夏季・冬季でともに 7 割程度と高く(Fig.14(a))、 天気や空方位とも関わりがない。さらに、夏季に比べ冬季では、才 ーガンジーカーテンの使用率が減少し、遮光カーテンの使用率が上 昇している。これは、オーガンジーカーテンが直射日光を受けると まぶしくなるという理由が挙げられる。また、夏季・冬季に関わら ずカーテンの使用率が高い理由として、視界の制御に使用している という点が挙げられる。空外部に住宅などが見える空、教室のレイ アウト上（黒板の配置上）黑板の背面にある空についてみると

(Fig.14 (b))、8 割以上で閉じられていた。一方で、学校の内側 に開かれた空、教室のレイアウトにより児童の視線がいかない空、 外部が見えなくなるように工夫を施した窓についてみると（Fig.14 (c)）７割程度開けられていた。観察調査の際に、 $\mathrm{T}$ 小の教員にカ ーテンを使用する理由を聞いたところ、児童の視線がいき空外に建 物や人通りが見えてしまう空は気が散らないようにカーテンを閉じ るが、そうでない空はカーテンを開けているとのコメントが得られ た。通常、小学校のカーテンは直射日光の遮蔽を目的に設置される。 しかし、2 校のカーテンの使用状況の調査から、カーテンを遮光以 
外にも使用しており、特に視界の制御という目的で使われている実 態が確認された。そのため、計画段階においてカーテンが直射日光 の遮蔽以外にも使用されることを考慮し、空から得られる明るさを 損なわずに、視界の制御を行う方法の検討や空外環境を考慮した採 光計画が必要と考えられる。

\section{5. 昼光利用促進の取り組み}

\section{1 取り組みの経緯}

4 章の調査より、 $\mathrm{M}$ 小・ $\mathrm{T}$ 小では人工照明を調節する習慣がない ことがわかった。そこで、採光条件・人工照明の点灯パターン・カ ーテンの使用状況等から判断して、より高い効果が見込める $\mathrm{M}$ 小に おいて、昼光利用促進に向けた取り組みを実施することとした。ま ず、晴天日に教室のカーテンを開けた条件で中心机上面照度・黒板 面照度の測定を行い注7)、その結果（Fig.15）を教員に伝え人工照明 の使用量を削減できそうか聞いたところ、28 教室中 12 教室が『で きそう』と回答した。しかし、その後の観察調査において、人工照 明の使用量の調節は行われておらず、全教室で点灯していることを 確認した。そこで、人工照明の使用量を調整する取り組みを行うこ ととし、協力学級を募った。取り組みを行う教室は、測定日の中心 机上面照度が推奨照度を満たした教室の中で、協力の申し出が得ら れた 5 年生の 2 教室とした。2 教室は並列に位置しており、両教室 の光環境は近い。1 教室において光環境の測定を行ったが、睛天日 では、照度・輝度ともに、推奨值及び規準值を十分に満たしている 教室であった。

\section{2 提案内容}

$\mathrm{M}$ 小は、天気に関わらず常に人工照明を全灯する状況があったた め、児童が人工照明の使用量を調節することで、照明エネルギーの 削減につなげる提案をした。具体的には、教室の鉛直面 2 か所に照 度計を設置し注 10 )、照度計の值を参考に人工照明の使用量を調節で きるような掲示物を作成し、児童に対して取り組みの説明をした。

掲示物は、照明スイッチに(1)〜(4)の番号をつけ、照明スイッチの 点灯パターンごとに照度值を示したものを作った。掲示物に記載し た照度は、測定した鉛直面照度から机上面照度 $500 \mathrm{~lx}$ を確保できる 鉛直面照度を基準とし、基準以上の值であればなるべく消灯するよ うに提案した。また、時限ごとの天気と消灯したスイッチの番号を 授業後に記入し、消灯できた人工照明の数に合わせて透明な入れ物 にビー玉を入れることで、消灯できた電気量を可視化する工夫をし た。これらは各学級の日直が行い、全ての児童が取り組みに参加で きるように配慮した。

取り組みの内容を、対象の教室に在籍する 5 年生の児童約 60 人 に、昼光利用を促進する取り組みの導入として事前説明をした。こ の時、行ってもらう取り組み内容の他に、片側採光の小学校と比較 した $\mathrm{M}$ 小の光環境に関する特徵、照明エネルギーを削減するべき理 由を説明した。取り組み期間は、説明をした当日から 1 ケ月間で実 施した。取り組みのスケジュールを Table 6 に示す。

\section{3 取り組み結果・考察}

取り組みを 1 ヶ月間継続した後、活動の振り返り学習として、事 前説明の復習や取り組み結果の報告を行い、児童に感想や意見を訊 ねた。また後日、取り組み実施教室の坚童を対象にした取り組みに 関するアンケートと、担任教員を対象にしたヒアリングを行った。

Table 6 schedule of the trial

Date of description: November 28, 2017

Term of demonstration: from November 28, 2017 to December 21, 2017

Date of review: December 21, 2018

Questionnaire: from December 21, 2017 to January 10, 2018

Date of hearing: January 10, 2018

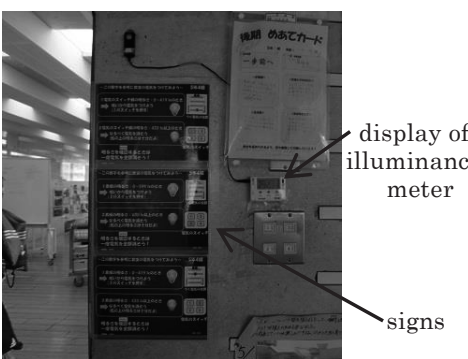

Fig. 16 Setting signs

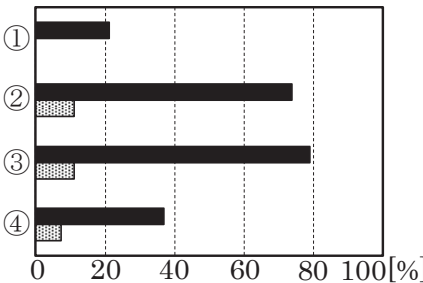

(a) Sunny day

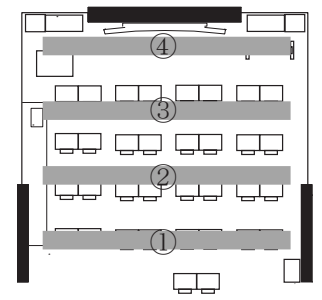

Fig. 17 Position of artificial lighting

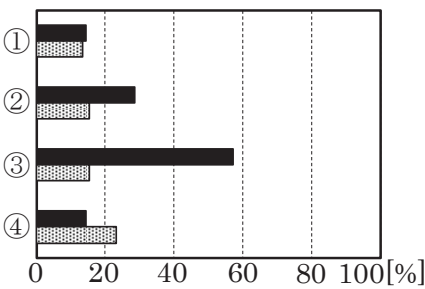

(b) Cloudy day

the first half $\quad$ the latter half (1) (4):reference Fig.17 Fig. 18 Lights-off ratio of artificial light (one month)

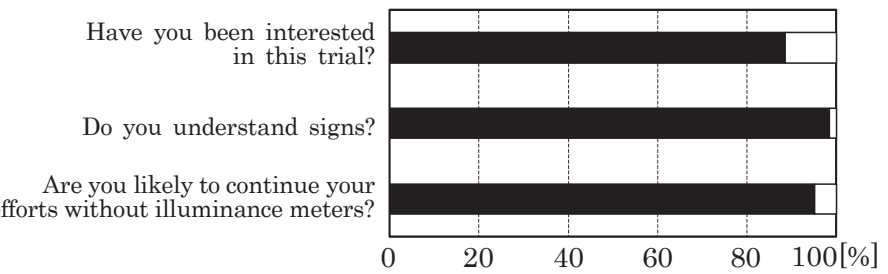

(a) Evaluation of the trial

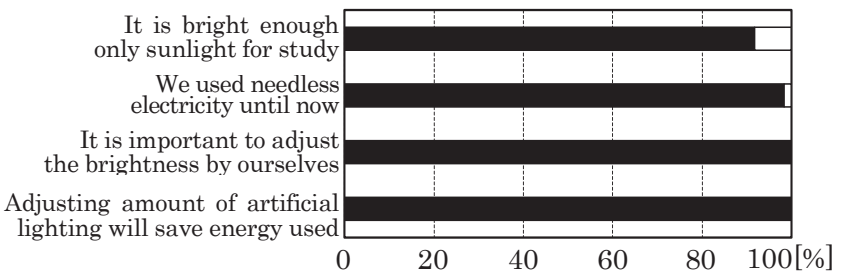

(b) The understanding of focusing point yes $\square$ no

Fig. 19 Results of questionnaire on children

\section{（1）児童の記録と観察結果}

児童が行った記録から求めた授業時の人工照明の消灯割合を Fig.18に示す。特に取り組み前半において、側㥶やハイサイドライ トから昼光を得られる(2)・ (3)の位置で、晴天で平均 $76 \%$ 、曇天で も $43 \%$ 消灯されていた。取り組みを通して人工照明の使用量を削 減できたことから、児童に昼光利用を促すことは、昼光利用促進の 手法として効果的であると考えられる。一方、取り組みの後半では、 前半より人工照明の消灯割合が低下しており、意識が薄れている様 子が見られた。観察調査においても、取り組みの前半では 2 教室と 
Table 7 Comments obtained from children

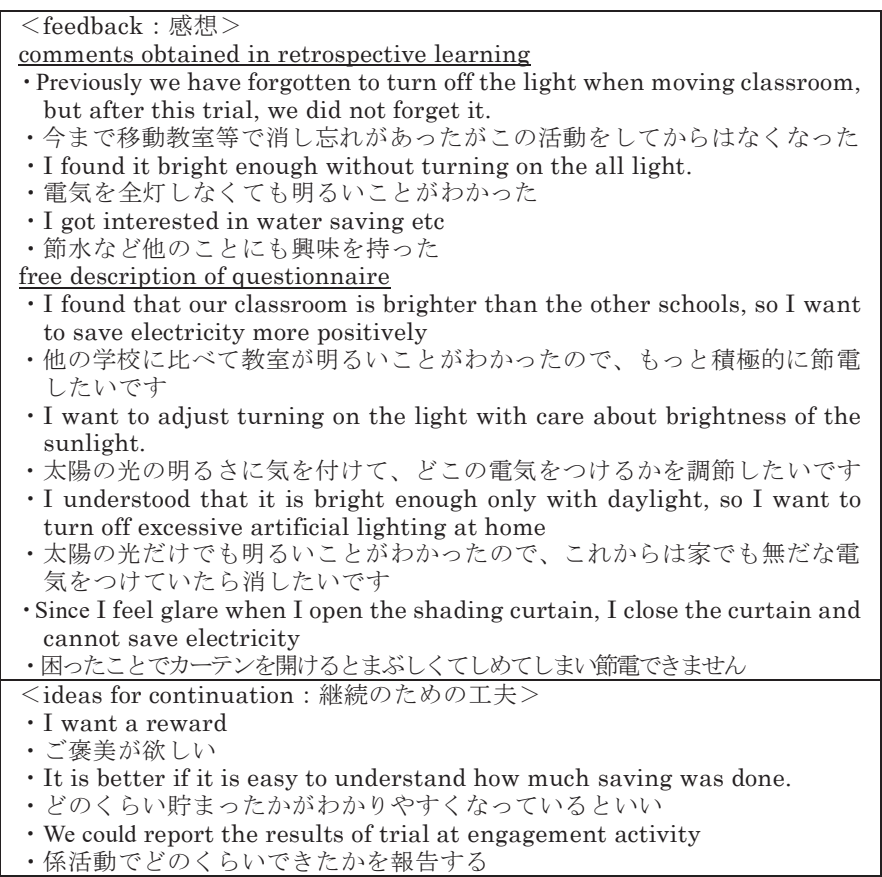

も使用量を調整していたが、後半では全灯する様子が見られた。こ の理由として、全ての児童が参加できるように日直を中心に取り組 んでもらったが、 1 ケ月間では日直は 1 人 1 回しか回らないことが 挙げられる。そのため、後半に日直が回ってくる児童は事前説明時 から 2 週間以上の期間が空いてしまい、その間に取り組みのことを 忘れてしまう児童が多くなり、習慣として定着させことができなか ったと考えられる。

\section{（2）取り組みに対する児童の評価}

アンケートの結果（61 名回答）を Fig.19に示す。また、振り返 り学習時に児童 9 名から得た意見を抜粋し Table 7 に示す。Fig.19 (a) より大半の児童が昼光利用の取り組みに興味を持ち、Table 7 より昼光から得られる明るさに応じて人工照明の使用量を調節する ことの大切さを理解し取り組んだと考えられる。振り返り学習時に 得た意見やアンケートの自由記述では、今回の取り組みを継続させ たいという意見以外にも、節水などの他の環境に関する取り組みに も興味を持った」、「自宅でも無䭾な電気を消したい」などこの取り 組みを展開した活動も指摘されていた。このことから、児童に対し て人工照明の使用量を調節するように働きかけることは、照明使用 量の削減につながるだけでなく、環境に配慮した生活を学習する機 会にもなることが考えられる。一方で、「カーテンを開けるとまぶし いので閉めてしまい、節電できない」という内容の記述があり、遮 光の重要性も確認された。

\section{（3）教員へのヒアリング}

取り組み終了後、対象教室の担任教員 2 名に取り組み時の児童の 様子や、意識が薄れていった要因などについて質問した。教員から 得られた意見を抜粋し Table 8 に示寸。取り組み開始当初は、児童 同士で話し合って消灯場所を決める等、児童の電気や明るさへの興 味・関心が高まっていたという感想が得られた。また、移動教室な どの際、教員に言われなくても教室の照明を消灯するようになった ことも大きな変化の一つとして挙げられた。後半に意識が薄れてい
Table 8 Comments obtained from teachers

$<$ behavior of children : 児童の様子 $>$
- At the beginning, children were working on the trial ambitiously by - At the beginning, children were working on the trial ambitio
talking "we can turn off now" or "we cannot turn off now".

・最初の頃は「今は消せる」「今は消せない」と話しながら意欲的に行っていた

- Children sometimes used to forget to turn off the light when moving classrooms before the trial, but they became to turn off without instruction after the trial.

・移動教室の時に言わないと消し忘れることもあったが取り組みを

行ってから言わなくても消灯するようになった

- Motivation of children for trial fell with the passage of time

・時間の経過とともに意欲は低下していった

- Children found that it is important to turn off wasted and excessive artificial lighting

・無駄・余分な電気を消灯する大切さが分かっていた

$<$ ideas for continuation : 継続のための工夫 $>$

- Since it does not last long if unrealized practice continues, it is better if there are recognitions, visible results and rewards

・実感のない実践が続くので長続きしないため、認められたり目に見える 形で結果があったりご裹美があると良い

- This skill is not able to be acquired without learning in class ・授業として学習しないと身につかない

- It is necessary that teachers themselves are also interested in this trial in order to enhance the motivation of children

・教員自身も関心を持ち、児童の意欲を高める

- When linking with class, there are no material that teaches us to use as much as necessary at present. It becomes easy to teach if we can obtain such materials

・授業とリンクさせる場合、必要な分だけ使うといったことを教えるよう な資料が皆無なので、そういった資料があるとやりやすい

ったことに関しては、効果の実感のない実践であったことが大きな 要因として挙げられた。今回の取り組みでは、ビー玉を貯めること で削減した電気量を可視化したが、児童に対して還元されるものが なかったため、実感が伴いにくく、取り組みへの意識が薄れていっ たと考えられる。 $\mathrm{M}$ 小では、児童の取り組みに対し一定のポイント が貯まると、45 分間レクリエーション時間を得られるシステムがあ るため、そういったものとつなげることができれば、習慣化しやす くなるとの指摘もあった。今後継続していくには、児童が取り組み の成果の実感を得やすいような工夫をし、児童の取り組みを評価す るような体制を学校全体で整えていくことが重要であると思われる。

\section{6. まとめ}

本研究では、積極的な昼光利用に向けて採光に工夫がみられる小 学校 2 校における調査から、光環境の実態と照明エネルギーの使用 量削減の可能性について考察した。

教室の光環境の測定結果より、南片側採光の標準設計型校舎と比 較して、採光面の多い教室の方が分布に偏りがない傾向が確認され た。また、夏季の測定日ではどの測定点においても推奨照度を超え ており、平均輝度も設計規準を十分に満たしていた。しかし、冬季 は直射日光の入射によりカーテンを閉めざるをえない状況があり、 その場合に照度が下がるケースや空面と教室内との輝度比が大きく なるケースも確認された。

遮光装置及び人工照明の使用状況の調査より、遮光装置は直射日 光が入射する場合だけでなく、視界を遮るためにも使われること、 人工照明は明るさに関わらず教室使用時には常に点灯されているこ とが実態として明らかとなった。

以上より、対象校の調査を通して考察した昼光利用により照明エ ネルギーを削減するための留意点をまとめる。まず、採光の方位・ 方式については、複数の採光面を設けることで、光環境の均一性は 高まるが、採光面が増えることで外部からの視線などの影響を受け 
やすくなるため、空外の環境に配慮する必要がある。遮光装置に関 わる留意点としては、直射日光の遮蔽にカーテンを使用する場合、 昼光を過度に遮蔽しないことと同時に、カーテン面のまぶしさや室 内との輝度比の増大を防ぐという観点から、光の透過率や拡散特性 を検討する必要がある。空外に住宅が近接する場合には、遮光目的 の他に視界を遮断するためにカーテンを使用することが多くなり、 採光に支障が生じる可能性がある。また、人工照明の分灯方式につ いて、採光面に応じて明るい空際が消灯でき、暗い室奥が点灯でき るような分灯方式とすることが必要である。

小学校において照明エネルギーを削減していくには、設計時の配 慮に加えて使用者の環境調整行動も必要となってくる。5 年生の児 童の協力を得て実施した人工照明の使用量削減に向けた取り組みで は、児童は内容や意義を理解し、人工照明の使用量やカーテンの開 閉を調節する様子も見られた。取り組みを習慣化するには至らなか ったが、児童が責任を持って人工照明の使用量の調節を行える仕組 みを整えることによって、照明エネルギー削減が実現する可能性が 確認された。

\section{謝辞}

本研究の実施にあたり、宗方淳教授 (千葉大学)、小﨑美希助教 (お 茶の水女子大学)、千葉市立美浜打瀬小学校・立川市立第一小学校の 教職員及び児童の皆様に多大なるご協力を賜りました。ここに記し て謝意を表します。また、本研究の協力者であった太郎田悠氏（平 成 29 年度明治大学 4 年生) に感謝致します。

\section{参考文献}

1) Architectural thought Institute: Data File of Architectural Design and Detail 16 School-elementary school $\cdot$ junior high school $\cdot$ high school -, Kenchiku Shiryo Kenkyusha CO., LTD., p. 6, 1987. 3 建築思潮研究所編:建築設計資料 16 学校一小学校・中学校・高等学校一, 建築資料研究社, p. 6, 1987. 3

2) The Committee on the Promotion of Zero Energetics School: Report of the Committee on the Promotion of Zero Energetics School 学校ゼロエネルギー化推進方策検討委員会 : 学校ゼロエネルギー化推進 方策検討委員会報告書, 2012.5

http://www.mext.go.jp/component/b_menu/shingi/toushin/_icsFiles/a fieldfile/2012/06/15/1321285_05.pdf (accessed 2018-1-30)

3) Naoya H. : Examination of the Validity of Various Brightness Indexes Based on the Brightness Rating in the Room Which Has a Scene Through the Window, Journal of Environmental Engineering (Transactions of AIJ), No. 615, pp. 9-14, 2007. 5

原直也：空外に景色を有する室の明るさ評価に基づく種々の明るさ指標 の有効性の検討, 日本建築学会環境系論文集, 第 615 号, pp. 9-14, 2007.5

4) Hideki Y., Takashi Y, Hiroyuki S. : Space Brightness Evaluation for Day-Lit Offices, Journal of the Illuminating Engineering Institute of Japan, Vol. 98, No. 11, pp. 593-599, 2014. 11

山口秀樹、丸山隆志、篠田博之：空面からの昼光導入が空間の明るさ感 に与える影響，照明学会誌，第 98 巻，第 11 号, pp. 593-599, 2014. 11

5) Ineko T., Minako M., Shin T., Etsuko M., Takaaki K., Hiroto T. : Development of Built Environment Learning Program for Suginami Eco-school, Case Evaluation in Ogikubo Primary School at the Initial Stage, AIJ Journal of Technology and Design Vol. 17, No. 36, pp. 755-758, 2011. 6

田中稲子、村上美奈子、谷口新、望月悦子、古賀誉章、高口洋人 : 杉並 区エコスクールにおける住環境プログラムの開発一荻窪小学校における 萌芽段階の事例評価一, 日本建築学会技術報告集, 第 17 巻, 第 36 号, pp. 755-758, 2011. 6

6) Takaaki K., Etsuko M., Yasuha M., Ineko T., Minako M., Shin T.,
Hiroto T., Tamae F. : Development of Built Environment Learning Program for SUGINAMI Eco-School. Part 8, Deployment of Program for Light and Lighting, Summaries of Technical Papers of Annual Meeting, Architectural Institute of Japan, Environmental Engineering- II , pp. 561-562, 2013. 8

古賀誉章、望月悦子、丸山愛葉、田中稲子、村上美奈子、谷口新、高口 洋人、藤野珠枝：杉並区エコスクールにおける住環境学習プログラムの 開発その 8 光に関する学習プログラムの開発, 日本建築学会大会学術 講演梗概集，環境工学-II , pp. 561-562，2013.8

7) Yoko U., Takaaki K., Etsuko M., Ineko T., Minako M. : Development of Built Environment Learning Program for SUGINAMI Eco-School. Part 9, Deployment of Program for Light and Lighting 2013, Summaries of Technical Papers of Annual Meeting, Architectural Institute of Japan, Environmental Engineering- II , pp .571-572, 2014. 9 内田陽子、古賀誉章、望月悦子、田中稲子、村上美奈子 : 杉並区エコス クールにおける住環境学習プログラムの開発その 92013 年度の光に関 する学習プログラムの開発, 日本建築学会大会学術講演梗概集, 環境工 学- II, pp. 571-572, 2014. 9

8) KINDAIKENCHIKU-SYA CO., LTD. : KINDAIKENCHIKU, Vol. 60, No. 8, pp .120-123, KINDAIKENCHIKU-SYA CO., LTD., 2006.8 株式会社近代建築社編 : 近代建築, 第 60 巻, 第 8 号, pp. 120-123, 株 式会社近代建築社, 2006.8

9) KINDAIKENCHIKU-SYA CO., LTD. : KINDAIKENCHIKU, Vol.69, No.7, pp. 88-91, KINDAIKENCHIKU-SYA CO., LTD., 2015.7 株式会社近代建築社編 : 近代建築, 第 69 巻, 第 7 号, pp.88-91, 株式 会社近代建築社, 2015. 7

10) Ministry of Education, Culture, Sports, Science and Technology Japan: Gakkokankyoeiseikijun (School Environmental Sanitation Standards) , 2009 文部科学省 : 学校環境衛生基準（平成 21 年文部科学省告示第 60 号）, 2009

http://www.mext.go.jp/a_menu/kenko/hoken/1353625.htm (accessed 2018-1-30)

11) Architectural Institute of Japan: Standards for Lighting Environment, Architectural Institute of Japan Environmental Standards, L0002-2016, AIJ, p. 49, 2016. 6

日本建築学会：照明環境基準 - 同解説, 日本建築学会環境規準, AIJES-L0002-2016, 日本建築学会, p. 49, 2016. 6

12) Akinori S., Kanako K., Jun M., Kuniko H. : A Study for Utilization of Daylight in a Newly-built Elementary School-Survey on Actual Use and Trial for Improvement-, Summaries of Technical Papers of Annual Meeting, Architectural Institute of Japan, Environmental Engineering- I , pp. 511-512, 2016. 8

芹澤彰典、上野佳奈子、宗方淳、橋本都子 : 新設小学校における昼光利 用の検討一使用実態の調査と改善に向けた試み一, 日本建築学会大会 学術講演梗概集, 環境工学- I , pp. 511-512, 2016. 8

13) Kanako U., Kuniko H., Ryoko K. : Study on Sound Environment of Open-plan School, Survey on Honcho, Utase, Mihamautase Elementary school, Journal of Environmental Engineering (Transactions of AIJ), Vol. 74, No. 643, pp. 1033-1041, 2009. 9 上野佳奈子、橋本都子、倉斗綾子：オープンプラン小学校の音環境に関 する研究, 日本建築学会環境系論文集, 第 74 巻, 第 643 号, pp. 1033-1041, 2009. 9

14) Kuniko H., Kanako U., Ryoko K., Kazuko A. : A Study on Classroom environment of Utase Primary School and Mihamautase Primary School, Evaluation of Open-plan School by Teachers and Children, Journal of Architecture and Planning (Transactions of AIJ), Vol. 74, No. 645, pp. 2347-2355, 2009. 11

橋本都子、上野佳奈子、倉斗綾子、赤松佳珠子 : 打瀬小学校・美浜打瀬 小学校の教室環境一児童・教師によるオープンプランスクールの評価と 実態一, 日本建築学会計画系論文集, 第 74 巻, 第 645 号, pp. 2347-2355, 2009. 11

15) Syota I., Ryoko K., Kuniko H., Kanako U. : Study on the Furniture Arrangement and the Way of Using in New Style Classroom - Case Study in Tachikawa Daiichi Elementary School-, Summaries of Technical Papers of Annual Meeting, Architectural Institute of 
Japan, Architectural Planning, pp. 369-370, 2015. 9 伊原翔汰、倉斗綾子、橋本都子、上野佳奈子 : 新たな教室空間における 家具配置とその使われ方に関する研究一立川市立第一小学校における ケーススタディー, 日本建築学会大会学術講演梗概集, 建築計画, pp. 369-370, 2015. 9

16) Katsumi Y., Kazuyoshi Y. : Physical Characteristics of Open Plan Classrooms and Municipal Guidelines for School Buildings in Tokyo, Toyama and Akita Prefecture Study on development and evaluation of open classrooms in elementary school Part1, Journal of Architecture and Planning (Transactions of AIJ), Vol. 74, No. 635, pp. 25-32, 2009. 1

山口勝巳、屋敷和佳 : 東京都・富山県・秋田県の公立小学校におけるオ ープンプラン型教室の整備状況と整備方針 小学校におけるオープン 型教室の整備と評価に関する研究その 1 , 日本建築学会計画系論文集, 第 74 巻, 第 635 号, pp. 25-32, 2009. 1

17) Miki K., Liuqing Y., Kotaroh H. : Research on Pleasant Darkness in a Restaurant Quantitative analysis of luminance distribution, Journal of Environmental Engineering (Transactions of AIJ), Vol. 82, No. 735 , pp. 425-433, 2017. 5

小㟝美希、楊柳青、平手小太郎 : 飲食空間における快適な暗さに関寸る 研究 輝度分布を考慮した定量的な把握，日本建築学会環境系論文集， 第 82 巻, 第 735 号, pp. 425-433, 2017. 5

\section{注}

注 1） 近年の小学校教室の面積としては、山口らの調査 ${ }^{16)}$ によれば、オー プンプラン型の小学校では $60 \mathrm{~m}^{2}$ 前半を中心に分布している。

注 2) Baumer 社製 CCD カメラ $(\mathrm{TGX} 13 \mathrm{c} 、 1392 \times 1040 、 20 \mathrm{fps} 、 140$ 万画 素)に Edmund Optics 社製フィッシュアイレンズ(焦点距離 $1.4 \mathrm{~mm}$ 左右・上下画角 $\left.185^{\circ}\right)$ を装着し、露出時間の異なる 16 条件で撮影さ れた等立体角射影の複数の画像から各点の輝度值を算出するソフト を用いた ${ }^{17)}$ 。

注 3）今回のケースでは、直射日光が当たっていた部分もグレア源となって いたため、教室の明るさの評価を目的とする照度・輝度の測定結果の 分析 (3.2 項) からは除外することとした。

注 4）夏季の測定では、すべての測定点において机上面照度は500 lx を超 えていた。

注 5）平均輝度の算出においては、輝度カメラによって算出された輝度分布 地 $\left(1\right.$ セル $\left.8.349 \times 10^{-6}[\mathrm{sr}]\right)$ を用い、対象範囲の平均值を算出した ${ }^{17)}$ 。 範囲の設定例を、下の付図に記す。白塗りの範囲が算出範囲となり、 黒塗りは算出範囲外である。平均輝度の算出結果から、輝度比(空面 平均輝度/教室内平均輝度) 算出した。教室内の輝度の算出方法につ いて、以下に T2-3 冬季の例で説明する。Appended Fig.1 の (1): 西空、 (2) OS、(3)直射日光の当たっている部分、(4)東空のうち、教室内平均 輝度の算出においては(1)〜 (4)を除外した Appended Fig.2 の白い部分 を対象とした。天井面輝度は Appended Fig. 3 に示寸部分について求 めた。室内との輝度比をとるための空は、高輝度かつ面積の大きい東 空(4)を空面として Appended Fig.4 に示す部分とした。

注 6）各校の内装仕上げ材は下記の通りである。

$\mathrm{M}$ 小 : 天井; 有孔 $\mathrm{PB}$ (白色)、壁 : RC 打放しの上 $\mathrm{GEP}$ 薄塗り塗装 $\mathrm{T}$ 小: 天井; 岩綿吸音板、壁; 化粧型枠 $\mathrm{RC}$ 打放しの上 $\mathrm{EP}-\mathrm{G}(2$ 倍希 釈)塗装

$\mathrm{S}$ 中：天井・壁(東西）；木質仕上げ、腰壁(南); RC 打放し白色塗装、 壁(北)；白色ボード・緑色掲示板

注 7）測定日及び条件は 3 章の夏季と同じで、測定時刻は 11:40 12:00 であ る。机上面の高さは、 $1 \cdot 2$ 年生が $550 \mathrm{~mm} 、 3 \cdot 4$ 年生が $650 \mathrm{~mm}$ 、 $5 \cdot 6$ 年生が $700 \mathrm{~mm}$ である。

注 8） Fig.3 においては、line A, B, C の順に照度が下がる結果が示されてい るが、 $\mathrm{T}$ 小での照明の分灯が line $\mathrm{A} \sim \mathrm{C}$ と平行であったのは 16 教室 中 5 室で、11 教室は line $\mathrm{A} \sim \mathrm{C}$ と直交するラインで照明が分灯され ていた。なお、line $\mathrm{A} \sim \mathrm{C}$ は、最も多く昼光が入る空に平行に空際か ら $\mathrm{A} \sim \mathrm{C}$ ラインを定めた。

注 9） T 小の教員は、オーガンジーカーテンを使用してもまぶしくないとき はオーガンジーカーテンを使用し、まぶしいときは遮光カーテンを使 用するといった形で使い分けており、使用理由は両カーテンを含めた 回答となっている。

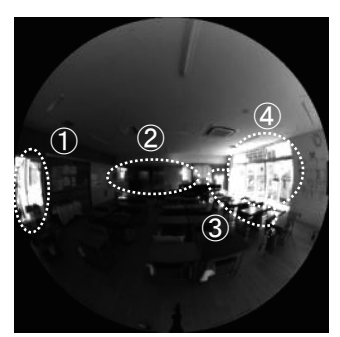

Appended Fig.1 Case with high luminance part by direct sunlight in classroom

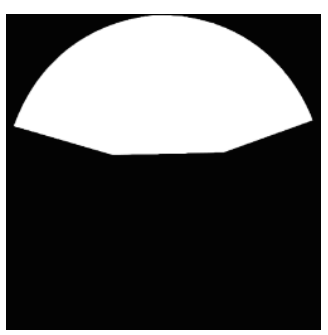

Appended Fig. 3 calculation range of average luminance of celling surface

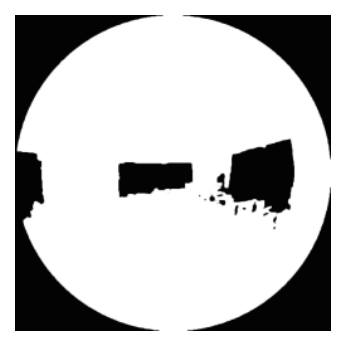

Appended Fig.2

Calculation range of average luminance of classroom in case with high luminance part by direct sunlight

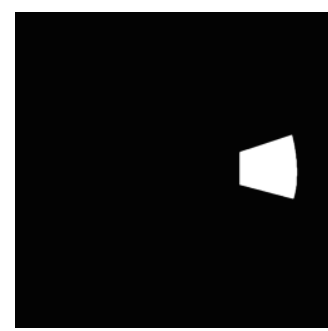

Appended Fig.4 calculation range of average luminance of window
注 10）児童が值を読む際、受光部に児童の影ができないような高さの鉛直面に 照度計を設置し、机上面が推奨照度 $500 \mathrm{~lx}$ を確保できる鉛直面照度を 調べるために照度測定を行った。提案を行った 11 月から 12 月にかけて は、晴天日では教室内に直射日光が入射し、カーテンを閉めて教室を使 用していたため、直射日光が入射する空のカーテンを閉めた状態で、人 工照明を消灯し測定した。測定から、照明のスイッチ横と教室後方机上 面 (Fig.2, C1)、黒板左端と教室前方机上面（Fig.2, A2）及び中心机上 面照度（Fig.2, B2）を対応させて掲示物の作成をした。 


\title{
A STUDY ON THE ACTUAL STATUS AND PROMOTION OF DAYLIGHT USE IN ELEMENTARY SCHOOL CLASSROOM
}

\author{
Akinori SERIZAWA *1, Kanako UENO *2 and Kuniko HASHIMOTO *3 \\ ${ }^{* 1}$ Graduate School of Science and Technology, Meiji University \\ ${ }^{* 2}$ Prof., Dept. of Arch., School of Science and Technology, Meiji Univ., Dr.Eng. \\ ${ }^{*} 3$ Prof., Dept. of Design, Faculty of Creative Eng., Chiba Institute of Technology, Ph.D.
}

School classrooms are obliged to set the aperture ratio to $1 / 5$ or more of floor areas according to the Building Standards Law, and a large window opening is provided. In recent years, in the design of school facilities aimed at energy saving, window design is contrived to realize daylight use. However, providing a large area for daylight and taking in more sunlight is not directly related to the reduction of lighting energy. It is necessary to improve the uniformity of luminance and remove glare through architectural design such as a daylighting method and shading devices. Also, it is needed for users to turn off artificial lighting when the luminance is sufficiently obtained by daylight. Therefore, it is necessary to organize the problems of a school's daylighting and lighting plan, including the user's environmental adjustment behavior.

This study aims to indicate the environmental light conditions of classrooms with contrived windows, the actual use of artificial lighting and light shielding devices, and the problems and the possibilities of daylight use in school buildings. In two elementary schools where the daylighting method was contrived, we measured the light environment and surveyed its use. Additionally, we conducted a trial to reduce the use of artificial lighting with the cooperation of teachers and children.

From the measurement result of the light environment in the classroom, it was confirmed that the distribution in the classroom with multiple windows is more uniform, compared with the standard design type of school building with windows on the southern one side. Also, in the classroom with multiple windows, the recommended illuminance was satisfied at any measurement point on a sunny day, and the average luminance also fulfilled the design criteria. However, in winter, when the curtain was closed to avoid the incidence of direct light, the brightness ratio between the window surface and the inside of the classroom was large.

According to the survey of the use of the light shielding device and artificial lighting, it was indicated that the light shielding device is not only used for direct sunlight but, also, for shielding the eyesight. Artificial lighting is always used regardless of the brightness in the classroom.

From our results, we summarize factors to pay attention to reducing energy consumption by the use of daylight in school buildings. In window design, it is important to make the distribution of brightness uniform. Concerning light shielding devices such as curtains, it is necessary to examine light transmittance and reflection characteristics to shield daylight appropriately and to prevent glare and a high luminance ratio. Additionally, it is necessary to consider a switch system for artificial lighting that can turn off light on a brighter side and illuminate a darker side.

To reduce lighting energy in school buildings, environmental adjustment actions of the user also become necessary. In the trial to reduce the amount of artificial lighting, which collaborated with fifth-grade children, it was seen that the children understood the objective and importance, and adjusted the amount of artificial lighting and curtain use. As a result, it was indicated that energy savings from reduced artificial lighting could be realized if children were led to understand the proper light environment and the method needed to adjust the level of artificial lighting. 